La Commission charge son Président de séance de prendre contact avec quelques astronomes spécialisés dans l'étude spectrométrique, spectrophotométrique, dans celle des mouvements propres, parallaxes, et vitesses radiales, en vue d'examiner l'éventualité de créer en son sein une sous-commission qui favoriserait la coordination des recherches effectuées ou à effectuer dans ces divers domaines et leur liaison avec l'aspect purement photométrique de la question.

M. Cox émet le vœu que cette sous-commission s'occupe de l'ordonnance dans les recherches qu'elle tenterait de coordonner et qu'elle ne craigne pas, si la nécessité s'en faisait sentir, de suggérer une refonte complète des programmes.

La Commission considère avec faveur la détermination quantitative, par chaque observateur de variables, de son équation de couleur, et suggère que le Prof. Guthnick veuille bien établir et publier à cette fin la liste de paires d'étoiles circumpolaires dont il recommande l'observation commune.

La Commission prend acte de la déclaration du Prof. Ludendorff, que le schéma de classification générale des étoiles variables qu'il a proposé ne répond plus, sur certains points, aux faits d'observation, ainsi qu'il l'a d'ailleurs déjà constaté lui-même dans le volume supplémentaire du Handbuch der Astrophysik, et elle forme le vœu qu'il puisse, lorsque le temps en sera venu, consacrer encore sa grande expérience du problème à ce sujet important.

A la suggestion de la Commission 29, la Commission appelle l'attention des observateurs spécialisés sur l'intérêt de la détermination rapide de magnitudes visuelles ou photovisuelles des étoiles de comparaison, y compris notamment les plus faibles, pour les novae récemment découvertes.

Enfin la Commission note qu'elle n'a pas reçu de rapport concernant l'organisation d'observations collectives, sous filtre, d'étoiles variables à longue période ou irrégulières. Elle forme le vœu que les séquences spéciales indispensables pour cette organisation soient promptement constituées.

\title{
COMMISSION 28 (NEBULAE AND STAR CLUSTERS)
}

\author{
President: Prof. H. Shapley. \\ Secretary: Prof. H. L. Vanderlinden.
}

Meeting on Thursday, August 4, I938.

The report submitted by the President of the Commission was adopted.

The Chairman's proposal to appoint a sub-commission on magnitude sequences was endorsed by the Commission. This proposal was as follows:

"That the Commission on Stellar Photometry (25) consider the appointment of a sub-commission on magnitude sequences, noting that for work on stellar distribution, variable stars, external galaxies, faint asteroids and faint proper-motion stars the need of more precise photographic and visual magnitudes is very great."

With respect to this Dr Baade remarked that it was possible to transfer the magnitude scale of the observed field to the Selected Areas until $m_{\mathrm{pg}}=\mathrm{I} 7 \cdot 5$. For certain Selected Area fields, e.g. S.A. 68, photographic magnitudes have been determined down to $2 \mathrm{r} \cdot 2$. Determinations will be extended to other S.A. fields.

As to the faint galaxies, according to Messrs Shapley, Adams, Reynolds, Baade, no general classification should yet be proposed for the brighter objects and Hubble's classification is as yet sufficient. 
Prof. Lindblad stated that from the theoretical point of view, exact measurements of the forms of the nebulae are sufficient.

The surface brightness is to be determined from microphotometer tracings on standardized plates.

For the determination of proper motions of galactic clusters, Dr Mineur's proposal was divided into two parts. The determination of relative proper motions remains within the competence of the present Commission.

As to the absolute proper motions, $\operatorname{Dr} A$. Vyssotsky introduced the motion:

"That the consideration of the methods of reduction of absolute proper motions of galactic clusters should be referred to the Commission 24, on Proper Motions and Parallaxes."

\section{COMMISSION 29 (STELLAR SPECTRA)}

President: Prof. H. N. Russell.

$\mathrm{Mr}$ Stratton, for the sub-commission on novae, exhibited a specimen sheet of the Atlas of the spectrum of Nova Herculis, which will consist of $\mathrm{x} 6$ plates showing the changes with time in the spectrum from $\lambda_{3} 600$ to $\mathrm{H} \alpha$.

In view of the importance of obtaining good light curves of the early stages of novae, the following resolution was unanimously adopted:

"That Commission 29 would welcome the assistance of Commission 27 in the organization of the early distribution of charts of comparison stars for bright novae and in the extension of the scheme of the A.A.V.S.O. for securing novae at the earliest possible stage."

Mrs Gaposchkin recommended (I) that photometric measures of the bright bands in the spectra of novae be made at as early stages as possible, (2) that observers employ a green screen in the determination of visual magnitudes.

$\mathrm{Mr}$ Adams reported on the spectra of recent supernovae. The bands are wide, and shift progressively. No identifications have yet been made, except a doubtful one with the forbidden line of OI at $\lambda 6300$. The spectra appear to be of an entirely new type.

The report of the sub-commission was then adopted. The report of the subcommission on the classification of Wolf-Rayet stars was discussed at length with special reference to the convenience of various alternative forms of notation as regards typewriting, printing and the preparation of manuscript for the printer. A notation with two capital Roman letters (e.g. WN 6) was adopted by six votes to three; and the report of the sub-commission was adopted.

Mr Merrill's suggestion that forbidden lines should be described as of "nebular type" or "auroral type" rather than simply by the adjectives "nebular" or "auroral" was unanimously adopted. Lines of the nebular type arise from transitions from the lowest metastable level to the ground state; those of the auroral type from higher metastable levels to this metastable level; while those from such levels to the ground state are of the "transauroral type". (This is the usage originally suggested by Boyce, Menzel and Payne.)

The suggestion of $\mathrm{Mr}$ Struve regarding the rotational velocity of stars was commended to the attention of spectroscopists, without formal recommendation. 